\title{
Nowe dane o biografii karaimskiego poety Szymona Kobeckiego
}

\author{
Mariola Abkowicz \\ Uniwersytet Adama Mickiewicza w Poznaniu, Wydział Neofilologii \\ Zakład Hebraistyki, Arameistyki i Karaimoznawstwa \\ Anna Sulimowicz \\ Uniwersytet Warszawski, Wydział Orientalistyczny \\ Zakład Turkologii i Ludów Azji Środkowej
}

\begin{abstract}
New facts in the biography of the Karaim poet Simon Kobecki
Summary: Irlar ("Songs"), a book containing Simon Kobecki's collection of poetry released in Kiev in 1904 is considered the first printed edition of the secular Karaim literature. Kobecki's poems which enjoyed popularity in the Karaim communities, were often reprinted in Karaim magazines issued in the first half of the $20^{\text {th }}$ century, as well as nowadays in the journal "Awazymyz" and in collections of poetry published in Lithuania. Biographical information added to those publications was usually brief or even mutually contradictory. Until today, even the basic biographical data, such as the dates of Kobecki's birth and death, has not been accurately established. Recent archival queries allowed to finally determine his birth date and provided us with new data on his professional career.
\end{abstract}

Keywords: Szymon Kobecki, Karaims, Karaim secular literature, Karaim poetry, Karaims in military service

Wydany w Kijowie w 1904 r. zbiór poezji Szymona Kobeckiego, zatytułowany Irłar („Pieśni”) jest uznawany za pierwsze wydanie drukiem świeckiej literatury karaimskiej. W literaturze rękopiśmiennej utwory o tematyce niereligijnej, 
częściej spotykane u Karaimów krymskich w zeszytach medżuma, u Karaimów litewsko-polskich są rzadkie. Tym większe znaczenie ma tomik Kobeckiego, na który składa się 25 utworów, w tym niezwykle popularna kołysanka Iry mamanyn tëšagi katny jaš uvlunun, znana też jako Jukła uwłum, występująca w kilku wersjach muzycznych, m.in. autorstwa Walentyny Łobanosówny.

Niektóre z utworów były przedrukowywane w karaimskich czasopismach. W ukazującym się w Moskwie miesięczniku „Karaimskaja Żizn'” opublikowano wspomnianą wcześniej kołysankę (1911a) oraz Kadril' (1911b). Aleksander Mardkowicz na łamach „Karaj Awazy” zamieścił pochodzące z kijowskiego tomiku utwory: Janhy jiłba, Iry mamanyn tesz'agi katny jasz uwłunun, Menim tüszüm, Sonet, Anar..., Elczilarym, Kyszyn, Gertma, Kadril (1936), a także ukazujące się po raz pierwszy drukiem Kim bołałyr (1932b) oraz San saja i Czeczaczek (1936). Spod pióra S. Kobeckiego wyszło również wspomnienie prozą Burunhu kiuń midraszta (1932a), które także znalazło się w wydawanym w Łucku czasopiśmie. Anonimowy autor nekrologu zamieszczonego w „Myśli Karaimskiej” wspomina o licznych bajkach, których autorem był poeta (podaje tytuł jednej z nich: Jawan Karajski da szejtan, czyli „Karaimski żołnierz i diabeł”), nie zachowały się one jednak (1932-1934: 102). Nie publikowane wcześniej wiersze, Erbi Medad (1939a) i Tuzsuz (1939b) ukazały się na łamach „Onarmach”, wydawanego na Litwie Kowieńskiej przez Michała Tynfowicza. Najobszerniejszy wybór poezji Kobeckiego znalazł się w tomie Karaj jyrlary opracowanym przez Michaila Firkoviča (1989), który umieścił tam w sumie 42 utwory poety, w tym 16 niepublikowanych wcześniej drukiem. W Čypčychlej učma Trochka, antologii poezji karaimskiej z przekładami na język litewski, wydanej w 1997 r. w Wilnie przez Karinę Firkovičiutè, znalazło się 12 wierszy Kobeckiego.

Całość Irłar w transkrypcji naukowej zamieścił Tadeusz Kowalski w Karaimische Texte im Dialekt von Troki. W komentarzach wspomina on także o innym zbiorku wierszy Kobeckiego, wydanym w Trokach „in der letzten Zeit” ('ostatnimi czasy')2 , również pod tytułem Irłar, w formie odbitki powielaczowej (Kowalski 1929: 291).

1 Kowalski zdecydował się zamieścić w swej monografii całą zawartość Irlar, gdyż jak wyjaśniał, tomik stał się rzadkością, a jego egzemplarze trudno było napotkać nawet wśród Karaimów (Kowalski 1929: 291). Trudno to wytłumaczyć, gdyż nakład Irlar był całkiem spory, wynosił bowiem 1000 egzemplarzy (1905: poz. 12417).

2 Oznaczałoby to, że zbiorek wydano w latach 20. - Kowalski odbył wycieczkę naukową do Trok i Wilna w 1925 r., a cztery lata później wydał Karaimische Texte. W „Myśli Karaimskiej” wspomniano jednak, że zbiorek ten, „odbity na hektografie”, ukazał się rok po Irlar, czyli w roku 1905 (1932-1934: 102). 
Wydane drukiem Irłar Kobeckiego szczegółowej analizie pod względem treści, formy i języka poddał Ananiasz Zajączkowski (1928). We wzmiance o Kobeckim w swoim wcześniejszym artykule Literatura karaimska. Szkic bibliograficzny Zajączkowski podaje, że „Kobecki był także autorem licznych komedyj, które do dziś dnia są pamiętne starszej generacji naszego społeczeństwa, wśród którego nie mało jest odtwórców ról tych utworów, tryskających wesołością i rodzimym humorem" (1926: 12). Wymienia w tym miejscu tytuły dwóch utworów: Mieniagień i Siuviarlik boszatat bar jazychłarny, zauważając, że „poza wymienionym tomikiem poezyj nie ukazało się w druku nic, a liczne rękopisy, znajdujące się gdzieś w Rosji, prawdopodobnie zaginęły” (1926: 12). Nie do końca jednak tak było, gdyż w przypisie do San saja w „Karaj Awazy” Mardkowicz (1936) podaje: „Bu jir da sondrahy cyhadłar jarykka burunhu for. Kol-jazysy ałarnym tabuładyr kołunda R. Szemaja Firkowicznin (Trokta)”3.

\section{Informacje o życiu poety}

Życiorys poety najwyraźniej nie był Zajączkowskiemu szczegółowo znany, gdyż poza trockim rodowodem poety późniejszy profesor Uniwersytetu Warszawskiego nie zamieszcza żadnych szczegółów biograficznych. Kowalski stwierdza jedynie, że „Der Verfasser, ein ehemaliger Oberst der russischen Armee, lebt noch hochbetagt in Russland"4 (Kowalski 1929: 291). Podobną, nieco obszerniejszą informację znaleźć można w nekrologu zamieszczonym w „Myśli Karaimskiej” (1932-1934). Anonimowy autor podaje, że Kobecki zmarł latem 1933 r. na Ukrainie, o czym wiadomość dotarła „przed paroma tygodniami” (ten numer MK obejmuje lata 1932-1934, mogło to więc być nawet kilkumiesięczne opóźnienie), a dalej pisze: „Sz. Kobecki, urodzony w Trokach, z zawodu był oficerem. Po przewrocie, jako dymisjonowany pułkownik b. armii rosyjskiej, osiadł na roli w południowej Rosji”. W dalszej części nekrologu następuje opis literackiej działalności Kobeckiego, przy czym nowym elementem jest wzmianka o niezachowanych bajkach jego autorstwa, takich jak np. Jawan Karajski da szejtan.

Aleksander Mardkowicz publikując w zeszycie dziewiątym „Karaj Awazy” wspomniane wcześniej wiersze, zamieścił krótką notatkę o ich autorze. Podaje

3 Karaim. 'Ten wiersz i następny ukazują się drukiem po raz pierwszy. Rękopis znajduje się w rękach R. Szemaji Firkowicza (w Trokach)'.

4 Niem. 'Autor, dawny oficer armii rosyjskiej, żyje jeszcze, w mocno zaawansowanym wieku, w Rosji'. 
w niej, że Kobecki „tuwdu Trochta ekińci jarymynda askan jizjiłnyn”. Wynika z tego jasno, że także Mardkowicz nie dysponował żadnymi ścisłymi danymi dotyczącymi biografii poety. Dalej bowiem pisze jedynie: „Jigit jiłłaryndan ezłendi ceriw zachmetine da jetti jergesin pułkowniknin ceriw chałkynda Rosijanyn. Tismeginden sortun caratnyn ołturdu sałada wajałatynda Kijownun, kajda ałyndy isine saban sirmeknin. Bu awur zachmette da katy tirlikte asty kałdyhy anyn kinłerinin. Ystyryłdy 1933 jiłda.”.

Rok 1865 jako data urodzenia Kobeckiego pojawia się po raz pierwszy w broszurce Pamięci Szymona Kobeckiego narodowego poety karaimskiego, wydanej w Wilnie w roku 1933 nakładem Towarzystwa Miłośników Historii i Literatury Karaimskiej. Zawarto w niej słowa i zapis nutowy melodii kołysanki Jukła uwłum, jak też portret i daty życia poety: 1865-1933. Daty te pojawiają się również w późniejszych publikacjach autorów litewskich (Firkovič 1989: 2; Firkavičiūtė 1997: 39; Zajončkovskis 1997: 41, 2005: 18; Kobeckaitè 2006: 326).

W słowniku biograficznym opracowanym przez Borysa Eliaszewicza daty życia zostały podane w przybliżeniu: około 1854 - około 1930 (1993: 103). Autor słownika rozszyfrowuje patronim (отчество), które na tomiku Irłar widnieje tylko w formie inicjału: S. A. Kobecki, jako Azariewicz (syn Azarii) oraz podaje informację, że poeta ukończył karaimską szkołę elementarną w Trokach (tzw. Midrasz) oraz szkołę wojskową w Wilnie, po czym wiele lat służył jako oficer. Przed rewolucją dosłużył się rangi podpułkownika i piastował stanowisko komendanta garnizonu w mieście Skwyra, w guberni kijowskiej.

Nazwa tej miejscowości pojawia się także na fotografii znajdującej się w zbiorach Józefa Sulimowicza, polskiego turkologa i kolekcjonera caraimików. Zdjęcie wykonane w atelier fotograficznym w Kijowie ma na rewersie dedykację dla ribbi Abrahama syna Szemoela Nowickiego ${ }^{7}$, datowaną w Skwyrze 2 sierpnia 1905 r. [Ryc. 1]. Dedykację uzupełnia wierszyk, który wskazuje, że na fotografii rzeczywiście został uwieczniony poeta Szymon Kobecki.

$5 \quad$ Karaim. 'urodził się w drugiej połowie minionego stulecia'.

6 Karaim. 'Od młodych lat związany był z wojskowym rzemiosłem i osiągnął rangę pułkownika w armii rosyjskiej. Po upadku caratu zamieszkał na wsi w guberni kijowskiej, gdzie został zatrudniony do orania pługiem. Na tym ciężkim trudzie i surowym życiu upłynęła reszta jego dni. Odszedł w 1933 r.'

7 Abraham Nowicki pojawia się na liście hazzanów w Łucku (1932), gdzie pełnił posługę w latach 1904-1905. W dedykacji na fotografii jest określany jako nieżonaty. W późniejszych latach Nowicki osiedlił się w Moskwie, gdzie po I wojnie światowej pełnił obowiązki hazzana (Mihailov 1999: 80). 


\section{Wykaz przebiegu służby i odtworzenie życiorysu S. Kobeckiego}

Podane przez Eliaszewicza dodatkowe informacje biograficzne (imię ojca, stopień wojskowy oraz ostatnie przed rewolucją miejsce zamieszkania i piastowane stanowisko) okazały się pomocne przy odtwarzaniu życiorysu poety, pozwalając potwierdzić, że autor tomu poezji, ofiarodawca fotografii i dowódca garnizonu w Skwyrze to ta sama osoba.

Dzięki współpracy z Romualdem Szpakowskim z Wilna, pasjonatem badającym losy Karaimów służących w przedrewolucyjnej armii rosyjskiej, i Olegiem W. Pietrowem z Moskwy, redaktorem naczelnym czasopisma „Karaimskije Vesti”, w Rosyjskim Państwowym Archiwum Wojenno-Historycznym w Moskwie udało się odnaleźć teczki osobowe Szymona Kobeckiego, syna Azarii (RPW-HA 1902a, 1902b, 1905), w których znajdują się dokumenty związane $\mathrm{z}$ jego drogą zawodową, w tym wykaz przebiegu służby [Aneks 1].

Odnalezione dokumenty, podobnie jak i inne, przechowywane w Bibliotece Wróblewskich Litewskiej Akademii Nauki w Wilnie, Litewskim Państwowym Archiwum Historycznym w Wilnie i Państwowym Archiwum Autonomicznej Republiki Krym w Symferopolu, pozwalają pokusić się o odtworzenie przebiegu drogi życiowej Kobeckiego. Pozwoli to skorygować pojawiające się w różnych opracowaniach błędne informacje, ustalić powiązania rodzinne poety oraz poznać uwarunkowania kulturowe i edukacyjne, które miały wpływ na zainteresowania i twórczość karaimskiego poety.

Szymon Kobecki przyszedł na świat 29 czerwca 1857 r. jako szóste, najmłodsze dziecko i trzeci syn Azariasza i Marii, mieszczan miasta Troki w guberni wileńskiej (LPAHW 1858: dom 30). Oboje rodzice byli wyznania karaimskiego. Jako 10-latek, czyli w roku 1867, rozpoczął naukę w karaimskiej szkole w Trokach, nie znając wówczas języka karaimskiego (Kobecki 1932a). Biorąc pod uwagę także fakt, że w Imperium Rosyjskim dzieci rozpoczynały edukację w szkole elementarnej, w tym także karaimskiej, w wieku lat 8 (Abkowicz 2015: 148), można przypuszczać, że rodzina Kobeckich mieszkała poza Trokami, stąd zwłoka w rozpoczęciu regularnej nauki przez przyszłego poetę. Brak znajomości języka karaimskiego wskazuje, że rodzina musiała żyć w niekaraimskim otoczeniu, np. na wsi, w arendowanej karczmie ${ }^{8}$.

Służbę wojskową Kobecki rozpoczął 25 stycznia 1878 r., wstępując tymczasowo, do chwili uzyskania właściwego przydziału, do 50 Zapasowego Batalionu

$8 \quad$ W karczmie położonej w lesie należącym do sędziego ziemi trockiej Römera mieszkał dziadek poety, Abraham syn Szymona Kobecki (LPAHW 1765). 
Piechoty na prawach jednorocznego ochotnika trzeciej kategorii. Zaciągnięcie się do armii rosyjskiej w tym trybie, czyli nie czekając na pobór, wiązało się z pewnymi korzyściami: ochotnik posiadający wykształcenie przynajmniej elementarne miał możliwość wyboru rodzaju wojsk, oddziału i miejsca przydziału, a służba trwała krócej (jeden rok). Mógł też po zdaniu eksternistycznie egzaminów uzyskać stopień oficerski lub zostać skierowanym do szkoły wojskowej. Zasady awansu były jasno określone - trzecia, najniższa kategoria, którą uzyskał Kobecki najprawdopodobniej ze względu na posiadane wykształcenie, dawała prawo awansu na stopnie oficerskie po trzech latach służby (Sologub 2010).

Tocząca się w tym czasie wojna rosyjsko-turecka ( 24 kwietnia 1877 - 3 marca 1878) budziła wśród wielu młodych ludzi chęć walki o oswobodzenie Bułgarów spod tureckiego panowania, a wstąpienie do armii stwarzało perspektywy kariery zawodowej w wojsku. Medal „В память русско-турецкой войны” (brązowy, na kombinowanej, błękitnej - andrejewskiej i żółto-czarnej - georgiewskiej, wstążce), widoczny na wspomnianej wcześniej fotografii [Ryc. 1a-b] na piersi Kobeckiego, świadczy, że brał on udział w tej wojnie.

\section{Odesska Szkoła Junkrów Piechoty i jej środowisko}

Po zakończeniu wojny ochotnicy, którzy wykazali się w służbie, byli kierowani do szkół wojskowych. W ten sposób Kobecki trafił w 1878 r. do Odesskiej Szkoły Junkrów Piechoty (Одесское пехотное юнкерское училище). Panas Saksagański (właśc. Afanasij Tobilewicz, 1859-1940), późniejszy wybitny ukraiński aktor, reżyser i działacz teatralny, został w tym samym czasie skierowany do tej samej szkoły, W swoich wspomnieniach pisze on: „w oczekiwaniu na egzaminy przez dwa tygodnie mieszkałem w koszarach przy ulicy Kanatnej. Kandydatów przyjechało około dwóch tysięcy, a do szkoły przyjmowano tylko 400 osób. Bez pieniędzy, bez środków do życia, poszedłem rozładowywać statek z węglem, zarabiałem 3 ruble na dzień. W ciągu dnia pracowałem, a wieczorem, w kąciku, przy kopcącej lampie starannie przygotowywałem się do egzaminów" (Saksaganskij 1932; Krasnova, Drozdovskij 2012: 109).

Rok wcześniej do tejże szkoły wstąpił inny jednoroczny ochotnik, również uczestnik wojny rosyjsko-tureckiej, Andrejs Pumpurs (1842-1902), przyszły narodowy poeta łotewski, przedstawiciel ruchu młodołotewskiego, autor eposu Lāčplèsis na motywach ludowych podań i opowieści.

Wydaje się, że pobyt w odesskiej szkole wojskowej odegrał ważną rolę w kształtowaniu literackich zainteresowań i świadomości narodowej młodego Karaima. W drugiej połowie XIX w. i w początkach wieku XX Odessa była 
nie tylko ważnym ośrodkiem kultury rosyjskiej, lecz także miejscem, gdzie kształtowała się narodowa kultura ukraińska. Od Wiosny Ludów następowało stopniowe przekształcanie się tożsamości imperialnej w narodową, a jednym z elementów tej przemiany była walka o równouprawnienie własnego języka i emancypację kulturalną (Hroch 2008). Ważną rolę odegrała w tym twórczość Tarasa Szewczenki (1814-1861), który jako pierwszy „podniósł mowę ukraińskich chłopów do rangi języka literackiego. Zaczął tworzyć w tym języku poezję" (Hrywna 2010). Saksagański, uczący się w szkole w tym samym czasie, co Kobecki, miał w zwyczaju, jak sam wspomina, zapisywać do zeszytu ulubione wiersze ukraińskiego wieszcza, czyli „Kobziarza”, tworząc w ten sposób własny „kobzarik”, z którym przyjechał do Odessy i w wolnym czasie czytał te wiersze kolegom. (Saksaganskij 1932; Brodavko 2005: 175).

Bez wątpienia atmosfera szkoły, mimo obowiązującego w niej wojskowego drylu, jak też atmosfera samego miasta, w którym współistniały różne narodowości i stykały się różne kultury, sprzyjały rozwijaniu zainteresowań humanistycznych kadetów, ich pasji literackich, a jednocześnie powalały rozwinąć się poczuciu tożsamości narodowej i rozbudzały miłość do rodzimego języka. Być może to właśnie dało impuls Kobeckiemu, obdarzonemu niewątpliwym talentem literackim, do tworzenia w ojczystym języku.

Naukę w Odesskiej Szkole Junkrów Piechoty Kobecki ukończył 19 lipca 1880 r. jako tzw. portupej-junker (z prawem do noszenia nopmyneu, koalicyjki) i jednocześnie zaliczony został do drugiej kategorii, co zapewniało szybszy dalszy awans. Dwa miesiące później otrzymał promocję na stopień podchorążego (ros. noдnpanорщик), a niecały rok później, wiosną 1881 r. awansował na stopień chorążego (ros. nрапорщuк) z przeniesieniem do 52 Wileńskiego Pułku Piechoty stacjonującego w Teodozji na Krymie. W pułku tym służył do roku 1887, pełniąc kolejno funkcje p.o. kwatermistrza (ros. исполняющийдолжность квартирмейстера) i kierownika pułkowej izby chorych (ros. заведующий околодкомполка), obozowego policmajstra (ros. лагерный полицмейстер), kierownika obozowej szwalni (ros. заведующий полковой щвальней) oraz skarbnika pułku. 14 września 1884 r. otrzymał kolejny awans na stopień podporucznika (ros. noдnopyuuк).

\section{Przebieg dalszej kariery Szymona Kobeckiego}

W lipcu 1887 r. Kobecki przeniesiony został do zarządu Powiatowej Komendantury Wojskowej ${ }^{9}$ w Małoarchangielsku w guberni orłowskiej (ros. Управление

9 Organ terytorialnej administracji wojskowej pełniący funkcje powiatowej komendy uzupełnień. 
Малоархангельского Уездного Воинского Начальника) jako naczelnik administracyjny (ros. делопроизводитель) i służył tam do roku 1896. W tym okresie awansował kolejno na porucznika (ros. nоручuк) i podkapitana (ros. umaбc-kaпитан). 15 grudnia 1892 r. został odznaczony orderem Św. Stanisława trzeciego stopnia, a 26 maja 1896 r. medalem za długoletnią służbę i medalem z okazji koronacji Mikołaja II.

W sierpniu 1896 r. został zwolniony ze służby, otrzymując w służbie cywilnej rangę asesora kolegialnego. Roczna przerwa w służbie mogła być spowodowana sytuacją rodzinną, być może chorobą ojca, który zmarł 24 maja 1897 r.

Rok później, w listopadzie 1887 r. powrócił do służby czynnej i został przydzielony do Zarządu Powiatowej Komendantury Wojskowej w Hajsynie w guberni kijowskiej na poprzednio zajmowane stanowisko i z przywróceniem stopnia wojskowego. 6 sierpnia 1900 r. za wysługę lat awansowany został na stopień kapitana (ros. каnumar). Pozostał w służbie do roku 1902, kiedy to z bliżej nieokreślonych przyczyn rodzinnych [Aneks 2] znów przeszedł w stan spoczynku. Kawaler, nie posiadający nieruchomości, w cywilu planował osiąść w Symferopolu na Krymie (RPW-HA 1902b: 2r-4r). W podsumowaniu służby czytamy, że dwukrotnie pełnił czasowo obowiązki powiatowego komendanta w Małoarchangielsku i dwukrotnie w Hajsynie. Dwa razy też otrzymał odznakę honorową za długoletnią nieskazitelną służbę wojskową.

Jeśli nawet osiadł na Krymie, jak planował, to nie zatrzymał się tam na długo. W lutym 1904 r. powrócił bowiem do służby, obejmując ponownie stanowisko naczelnika administracyjnego w zarządzie Powiatowej Komendantury Wojskowej w Skwyrze podlegającego - podobnie jak komendantura w Hajsynie - pod kijowski okręg wojskowy. W maju 1904 r. decyzją Sztabu Generalnego zaliczono mu do służby okres, w którym przebywał w cywilu (RPW-HA 1905).

Dzięki informacjom zawartym w wydawanych corocznie informatorach o kadrze oficerskiej rosyjskiej armii według stanowisk (Obŝij spisok" oficerskim" činam" Russkoj Imperatorskoj Armii) za lata 1909 i 1910 oraz według stopni oficerskich (Spisok" kapitanam" po staršinstvu i Spisok" podpolkovnikam" po staršinstvu) za lata 1911-1913, można prześledzić dalszą karierę zawodową Kobeckiego: w latach 1909-1910 zajmował stanowisko powiatowego komendanta wojskowego w Skwyrze oraz naczelnika służb administracyjnych (1909: 72; 1910: 73; 1911a: 631). 21 marca 1911 został odznaczony orderem Św. Anny 3 stopnia (1913b: 1406).

Wkrótce potem miało miejsce zdarzenie, które może świadczyć zarówno o popularności Kobeckiego wśród Karaimów, jak i o szacunku i zaufaniu, jakim go darzyli. W wyborach na wakujące po śmierci Romualda Kobeckiego (1823-1911) stanowisko hachama trockiego, odbytych w Trokach 16 sierpnia 
1911 r., została zgłoszona jego kandydatura (1911b: 116). Kontrkandydatem był Seraja Szapszał, który otrzymał głosy trzech z pięciu delegatów gmin Zachodnich Guberni (Trok, Łucka, Poniewieża, Wilna i Pskowa-Ostrowa), Kobecki zaś dwa (Bałaban 1927: 72). Okazało się jednak, że obie kandydatury zgłoszono bez wiedzy i aprobaty kandydatów i obaj odmówili. Szapszał swą odmowę motywował brakiem odpowiedniego przygotowania, zapewne jednak właściwą przyczyną był zamiar ubiegania się o bardziej prestiżowe stanowisko hachama taurydzkiego, które lada moment miało zostać zwolnione przez starego i schorowanego Samuela Pampułowa (1911b: 117). Jakie powody swej decyzji podał Kobecki, tego, niestety, nie wiemy.

Ostatnia notatka w przebiegu służby zawiera informację, że w marcu $1912 \mathrm{r}$. został oddelegowany do Dubna w guberni wołyńskiej jako kwatermistrz podlegającego pod skwyrską komendanturę Dubieńskiego Batalionu Karnego (ros. Дубненский дисциплинарный батальон). Relokacja ta - i awans - znajdują potwierdzenie w spisie podpułkowników za rok 1912 r. Kobecki figuruje tam w wykazie zmian, które nastąpiły między 1 maja, gdy zamykano zasadniczą część wydawnictwa, a 15 października, gdy oddano je do druku, jako kapitan piechoty awansowany na wyższy stopień. (1912: 9). W spisie podpułkowników za $1913 \mathrm{r}$. zamieszczono go już we właściwej części, z podaniem dokładniej daty awansu na stopień podpułkownika: 26 sierpnia 1912 r. $(1913 b: 1406)^{10}$. W Dubnie w roku 1914 zajmował stanowisko szefa intendentury (ros. заведующий хозяйством) (1913a: 410). Jego batalion w latach 1910-1915 stacjonował w koszarach fortu w Dubnie. W chwili obecnej nie wiemy, jakie były losy Kobeckiego po wybuchu I wojny światowej. Informacji o jego służbie nie znajdujemy w księdze pamiątkowej guberni wołyńskiej na rok 1915, gdyż skład personalny jednostek wojskowych, oprócz zarządu komendantury powiatowej (1915: 393), nie został tam wyszczególniony.

Baza danych o uczestnikach ruchu białych w Rosji, będąca efektem badań prowadzonych przez historyka Siergeja Wołkowa, a gromadząca na podstawie dokumentów archiwalnych informacje o losach oficerów imperialnej armii rosyjskiej w czasie I wojny światowej i wojny domowej 1918-1920, odnotowuje

10 W notatce z wyborów hachama zamieszczonej w „Karaimskoj Žizni” (1911b: 116) figuruje jako podpułkownik w stanie spoczynku (отставной подполковник), chос́ pozostawał wtedy w służbie czynnej. W cytowanym tamże artykule z wileńskiej gazety „Severo-Zapadnee Slovo” (w rzeczywistosci „Severo-Zapadnaâ Žizn”) dotyczącym odmowy Szapszała wspomniany jest natomiast jako подполковник въ запасп 'podpułkownik rezerwy' (1911b: 117). 
aktywność Kobeckiego w Armii Ochotniczej, w oddziałach noworosyjskiego regionu Sił Zbrojnych Południa Rosji operujących w okolicach Półwyspu Krymskiego. Pod datą 14 grudnia 1919 r. zarejestrowano jego udział - nadal w randze podpułkownika - w Nikołajewskiej Komisji Rekwizycyjnej (Volkov 2014).

Dalsze losy Kobeckiego mogą być jedynie przedmiotem spekulacji, gdyż jak dotąd nie udało się natrafić na żadne dotyczące go dokumenty. Po klęsce wojsk białych i zajęciu Krymu w 1920 r., musiał, podobnie jak wielu mieszkańców ZSRR o nieodpowiednim z punktu widzenia władz komunistycznych życiorysie, ukrywać wojskową przeszłość, by uniknąć prześladowań, które spotykały białych (Tinčenko 2011, 2012). Jego losy od 1920 r. do śmierci nadal czekają na

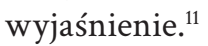

Jak można przypuszczać na podstawie informacji o skierowaniu go pod koniec życia do pracy jako oracz (Mardkowicz 1936), Kobecki mógł zostać objęty akcją przymusowej kolektywizacji i rozkułaczania wsi rozpoczętą przez władze sowieckie pod koniec lat 20., po odejściu od programu gospodarczego NEP. Polityka terroru wobec chłopów - aresztowania, deportacje, zwiększone kontyngenty nakładane na wsie, blokady dostaw żywności - spowodowała w latach 1930-1933 załamanie się cyklu produkcyjnego rolnictwa na Ukrainie, co doprowadziło do klęski głodu na ogromną skalę. Niewykluczone, że jedną z około 6 milionów ofiar Wielkiego Głodu był karaimski poeta.

Informacja o jego śmierci, która dotarła do Wilna, Trok i Łucka była nieprecyzyjna (lato 1933, wieś pod Kijowem); nie znamy ani daty dziennej, ani nazwy miejscowości, ani przyczyny zgonu. W czasie głodu, którego wystąpienie było ukrywane i negowane przez władze, a informacje o nim były objęte najwyższą tajemnicą państwową niemal do końca istnienia ZSRR (Rajca, Łesiów 2005: 108; Bruski 2008: 339), nie powstawały żadne oficjalne wykazy strat. Relacje świadków mówią wręcz o zakazach sporządzania aktów zgonu i podawania głodu jako przyczyny śmierci, konfiskatach ksiąg metrykalnych. Pierwsze listy ofiar zaczęto sporządzać na podstawie zeznań tych, którzy przeżyli, dopiero w latach 80 XX w. (Rajca, Łesiów 2005: 101-104; Bruski 2008; Kulczycki 2008). Skłania to do postawienia pytania: czy Eliaszewicz (żyjący w latach 1881-1971, a więc świadek wydarzeń) znał prawdziwą datę, lecz świadomie podał przybliżoną, wcześniejszą o trzy lata, by uniknąć posądzenia o aluzje do Wielkiego Głodu?

${ }^{11}$ W Knigie učèta lic sostojaŝich na osobym učietie byvšych bielych oficerow w organach GPU Ukrainy, Harkov 2012 (oficerowie na literę K: tom II, s. 814) Kobecki nie figuruje. 


\section{Błędne informacje biograficzne i mity dotyczące Kobeckiego}

Słownik Eliaszewicza stał się źródłem informacji biograficznej nie tylko nie weryfikowanej, lecz także swobodnie przekształcanej przez autorów rosyjskich. Daty urodzin i śmierci poety, których Eliaszewicz nie był pewien (albo obawiał się podać), Aleksander Fuki w swoim opracowaniu Karaimy - synoviâ $i$ dočeri Rosii poświęconym udziałowi Karaimów w wojnach toczonych przez Rosję w XIX i XX w., podaje jako ostateczne: 1853-1930 (1995: 40). Wymienia też imię Serafim jako świecki odpowiednik imienia religijnego Simcha (Szymon, ros. Семён), uznając najwidoczniej podane przez Eliaszewicza imię Sima, czyli krymski odpowiednik Simchy, za zdrobnienie od rosyjskiego imienia Serafim (ros. Серафим). A. Fuki błędnie informuje o udziale poety w wojnie rosyjsko-japońskiej (1904-1905) - jak wynika z wykazu przebiegu służby, Kobecki przebywał podówczas w Skwyrze. Nie ma wątpliwości, że pozostawał w czynnej służbie w czasie I wojny światowej, nie jest jednak prawdą, że uzyskał wtedy stopień pułkownika-inżyniera. W ciągu swej kariery służył w piechocie, w pionach porządkowym i administracyjnym rosyjskiej armii i nie zmienił swej wojskowej specjalizacji. Do roku 1919 nie otrzymał też stopnia pułkownika. Opracowanie Fukiego powstało w czasie, gdy rosyjskie archiwa wojskowe nie były jeszcze dostępne, stąd gdy autor opisuje marzenia Kobeckiego o pracy naukowej i ich konfrontację z rzeczywistością służby wojskowej, widać wyraźnie, że źródłem informacji w tym względzie mogła być jedynie wyobraźnia.

Syn Aleksandra Fukiego, Ilia, w swoich szkicach Skvoz' veka $i$ kontynenty rozbudowuje legendę Kobeckiego, dodając informację, że za zasługi wojenne podczas wojny rosyjsko-japońskiej został on dwukrotnie odznaczony krzyżem św. Jerzego (2001: 273). Mamy tu jednak co najmniej dwie sprzeczności. Odznaczenie było przyznawane za zasługi w boju, tymczasem, jak było wyżej wspomniane, Kobecki udziału w walkach nie brał. Po wtóre, w 1828 r. zniesiono możliwość przyznawania orderu oficerom zaplecza, a w 1855 zrezygnowano z nadawania go za długoletnią służbę, nie mógł go więc otrzymać w inny sposób. Poety nie znajdujemy więc na listach kawalerów orderu św. Jerzego z lat 1904-1905 (Dubenskij 1904-1905).

Karaimskaâ Narodnaâ Encyklopedâ wymienia Szymona Kobeckiego, zapewne za ojcem i synem Fuki, na liście uczestników wojny rosyjsko-japońskiej (2006: 395) i pierwszej wojny światowej, podając za Eliaszewiczem błędne daty życia: 1854-1930 (2006: 395, 396). Także Michał Zajączkowski w swoich albumach poświęconych Karaimom w służbie wojskowej, zamieszcza za A. Fukim (1995) nieprawidłowe daty życia Kobeckiego (1997: 41, 2005: 18). Mylna informacja 
o wojskowej karierze poety została powtórzona również w katalogu wystawy „Karaj jołłary - Karaimskie drogi. Karaimi w dawnej fotografii” (Abkowicz, Sulimowicz 2010: 83).

\section{Identyfikacja fotografii}

Podobizna Szymona Kobeckiego [Ryc. 2] zamieszczona w „Myśli Karaimskiej” (1932-1934) oraz w wydanej z okazji śmierci poety ulotce z Kołysanka (Towarzystwo Miłośników Historii i Literatury Karaimskiej 1933), a następnie w „Karaj Awazy" (1936) [Ryc. 3], pochodzi być może z lat 1878-1880, czyli z początków jego kariery wojskowej ${ }^{12}$. Odbitka, która znajduje się obecnie w zbiorach $\mathrm{Mu}$ zeum Etnograficznego w Trokach [Ryc. 4a-b], została wykonana w Bachmucie, $\mathrm{w}$ atelier znanego miejscowego fotografa Jechiela Jankielewicza Lwowa. Nie jest jednak jasne, jakie związki łączyły Kobeckiego z tą miejscowością. Na fotografii uwieczniono poetę z ojcem i prawdopodobnie którąś z sióstr. Noszony przezeń mundur junkra ma pagony bez oznaczeń, brakuje też koalicyjki. Być może zdjęcie to znajdowało się w rodzinnym albumie siostrzenicy poety, Marii Maleckiej, mieszkającej w latach 30 XX w. w Trokach (BWLAN 1934 r.) albo jego dalszego krewnego ${ }^{13}$ Józefa syna Juliana Firkowicza, zmarlego w Trokach w 1927 r. (AKZDwT, 1927). Należący do Józefa egzemplarz Irlar opatrzony dedykacją autora [Ryc. 5] jest przechowywany w zbiorach Haliny Kobeckaitè.

W 1992 r. w Warszawie miała miejsce prezentacja wystawy poświęconej mniejszościom narodowym, zatytułowanej „Inni wśród swoich”, na której znalazły się również karaimskie zdjęcia, m.in. te udostępnione przez Walentynę z Łobanosów Sulimowicz (1912-1997), a pochodzące z albumu jej matki, Heleny z Ławreckich Łobanosowej (1882-1958). Na odwrocie zbiorowego zdjęcia [Ryc. 6a-b] Walentyna Szulimowicz zanotowała, że jeden z widocznych tam mężczyzn to „Szymon Kobecki - ten, który pisał wiersze (kołysanka)”. Sugerowałoby to, że mężczyzną tym jest poeta Szymon Kobecki - pod określeniem „kołysanka” kryje się wspomniana już pieśń Jukła uwłum, której słowa stanowi wiersz Kobeckiego. Jest to jednak błędny trop. Przedmiotowa fotografia jest

12 Niewykluczone jednak, że zdjęcie zostało wykonane później, około roku 1897, gdy Kobecki ze względu na sytuację rodzinną przerwał czynną służbę wojskową. Wskazywałby na to także fakt, że atelier Lwowa działało w Bachmucie w końcu lat 90. XIX w.

13 Ojciec Szymona Kobeckiego i matka Juliana, ojca Józefa, byli rodzeństwem. Józef był więc ciotecznym bratankiem poety, jednakże jak to często bywało w wielodzietnych rodzinach, byli niemal równolatkami (Józef ur. 1855). 
jedną z całej serii zdjęć przedstawiających grupę rówieśniczą Heleny Ławreckiej, zwanej Lolą. Podobnie jak i ona, mężczyzna na fotografii musiał być urodzony około roku 1880 r., podczas gdy poeta, rocznik 1857, należał bez wątpienia do poprzedniej generacji. Tym niemniej obu łączy dość wyraźne podobieństwo, co rodzi przypuszczenie, że być może to syn kogoś z rodzeństwa, ewentualnie dalszych krewnych poety. Niewykluczone, że również nazywał się Szymon Kobecki (co mogło spowodować mylną identyfikację) - imię to występowało w rodzinie Kobeckich dość często ${ }^{14}$.

\section{Rodzina Szymona Kobeckiego}

Odszyfrowanie otczestwa Kobeckiego przez Eliaszewicza, a obecnie ustalenie także jego daty urodzenia pozwalają pokusić się o odtworzenie genealogii poety. Jego ojciec, Azariasz, figuruje w spisie Karaimów - mieszkańców Trok z roku 1834 jako 20-letni syn Abrahama Kobeckiego syna Symona (LPAHW 1834: dom 30).

W „Regestrze Karaimów trockich” z roku 1764 (LPAHW 1765) znajdujemy Symona Kobeckiego, zapisanego jako Kubecki, członka trockiej gminy karaimskiej, mieszkającego w karczmie w lesie sędziego ziemi trockiej Römera (1860: 113). Żonaty z Deborą, miał dwóch synów, Jakuba i Abrahama oraz dwie córki, Niechamę i Chlemę. To pradziad Szymona Kobeckiego. W tym samym domostwie mieszkała też matka Symona z dwojgiem jego młodszego rodzeństwa, Józefem i Sesonitą.

W spisie za rok 1811 (LPAHW 1811: dom 19) figuruje syn Symona, Abraham (ur. ok 1760), dziadek poety. Jego żoną jest Anna córka Józefa (ur. ok. 1775). Mieli synów Symona (ur. ok 1790) i Salomona (ur. ok. 1800) oraz córki Sarę (ur. ok. 1794) i Judytę (ur. ok. 1803, według spisów późniejszych - ok. 1800). Najstarszy ich syn, Symon, jak odnotowano w spisie, był już w tym czasie studentem medycyny na wileńskim uniwersytecie. Warto w tym miejscu wspomnieć, że syn Symona, Feliks, w przyszłości również ukończył studia i rozpoczął karierę urzędniczą (LPAHW 1858: dom 30).

Podczas spisu w 1834 r. odnotowano kolejne dzieci: ojca poety, wspomnianego Azariasza (ur. ok. 1814) oraz Osipa (ur. ok. 1818) (LPAHW 1834: dom 30). Azariasz pojawia się też jako sygnatariusz przysięgi karaimskiej dla Mikołaja Pawłowicza

14 Przykładem może być Szymon Kobecki (1911-1985), również obdarzony talentem literackim, autor licznych humorystycznych wierszy opisujących życie społeczności karaimskiej w Trokach. Por. Kobeckaitè (2011). 
w 1844 r. (BWLAN 21 czerwca 1844 r: 4r). W roku 1858 Azariasz był już żonaty z Marią, córką Szymona, z którą miał sześcioro dzieci - synów: Zenona (Jazanię), lat 20, Abrahama, lat 7 i rocznego Simę (Szymona, przyszłego poetę) oraz córki: Annę, lat 19, Kamilę, lat 17 i Basię, lat 10 (LPAHW 1858: dom 30).

Szymon Kobecki rodziny nie założył. W trockich księgach metrykalnych znajdujemy za to zapis z 1881 r. o ślubie jego brata, Abrama syna Azarii Kobeckiego, podówczas 30-letniego, z Anną córką Josifa Kobecką, liczącą lat 18 (BWLAN 1869-1895: 98r). Co ciekawe, w księgach trockich nie odnotowano narodzin dzieci z tego związku - albo para pozostała bezdzietna, albo zamieszkała poza Trokami, a jej potomstwo zarejestrowano w aktach innej gminy, tak jak to miało miejsce w wypadku drugiego brata, Zenona, którego ślub 10 listopada 1860 r. z Mamuk, córką Dawida Feruza, wpisany został do ksiąg metrykalnych kienesy w Perekopie (PAARK 1860). Rodzi to przypuszczenie, że wszyscy trzej bracia Kobeccy opuścili Troki, przenosząc się na południe Rosji. Pośrednim potwierdzeniem tego może być też fakt, że Szymon wstąpił do 50 Zapasowego Pułku Piechoty, która to jednostka, wchodząca w skład 3 Rezerwowej Dywizji Piechoty, stacjonowała na Kaukazie.

W Trokach pozostała siostra poety, Batszeba (Basia), która 17 stycznia 1874 r. wyszła za maż za Józefa Maleckiego (BWLAN 1869-1895: 89r). Z tego małżeństwa przyszło na świat kilkoro dzieci, w tym wspomniana wcześniej siostrzenica poety, Maria.

\section{Podsumowanie}

Sprzeczności w biografii Szymona Kobeckiego były tematem wystąpienia autorek artykułu podczas IV Ogólnopolskiej Konferencji Turkologicznej w Poznaniu w 2010 r. Ówczesny stan wiedzy nie pozwalał jednak na ostateczne rozstrzygnięcie wielu kwestii. Wynikało to przede wszystkim z niekompletności archiwów karaimskich i braku dostępu do rosyjskich archiwów wojskowych. Sześć minionych lat przysłużyło się jednak badaniom. Otwarcie dostępu do archiwów wojskowych w Rosji oraz digitalizacja i udostępnienie w Internecie różnego rodzaju publikacji źródłowych, takich jak informatory i księgi pamiątkowe, pozwoliło poszerzyć wiedzę o biografii karaimskiego poety. Udało się ustalić jego datę urodzenia i przebieg służby wojskowej do 1919 r. Wciąż wiele kwestii pozostaje jednak nieustalonych. Badania nad losami Szymona Kobeckiego będą kontynuowane, co pozwala żywić nadzieję, że poznamy dokładniej jego losy w czasie I wojny światowej, przebieg ostatnich lat życia i okoliczności śmierci w sowieckiej Ukrainie. 


\section{Archiwa i Biblioteki}
AKZDwT = Archiwum Karaimskiego Zarządu Duchownego w Trokach
BWLAN = Biblioteka Wróblewskich Litewskiej Akademii Nauk w Wilnie
LPAHW = Litewskie Państwowe Archiwum Historyczne w Wilnie
PAARK = Państwowe Archiwum Autonomicznej Republiki Krym w Symferopolu
RPW-HA = Rosyjskie Państwowe Wojenno-Historyczne Archiwum w Moskwie

\section{Bibliografia}

\section{Dokumenty archiwalne}

AKZDwT, 1927, Trockie księgi metrykalne. O zmarłych, Troki.

BWLAN, 21 czerwca 1844 r, Klâtvennoe obéŝanie, Przysięga karaimska dla Mikołaja

Pawłowicza za 1844 rok. F301-180: 3r-4r.

BWLAN, 1869-1895, Trockie księgi metrykalne, Troki. F301-288.

BWLAN, 1934 r., Do Zarządu Duchownego Karaimskiego w Trokach, Teczka korespondencji za 1934 r., Troki F301-420.

LPAHW, 1765, Miasto Troki. Regestr Karaimów Trockich przez Jmego Pana Thadeusza Kuszelewskiego Rewizora od WPPu Jozefa De Raesa Woyskiego y Podwojewodzego Dominika Tańskiego Podstarościego Urzędników wwodztwa Trockiego oraz Abrahama Łabanosa Woyta Synagogi Karajmow Litewskich Ezreasza Symonowicza Zoracha Raeckiego starszych Kahalnych zastanych sporządzony et die 16. Januarii Anno 1765 Przed nami komisarzami w mieście Trokach zaprzysiężony, Troki SA-3732.

LPAHW, 1811, Rewizska skazka. Roku 1811 Mca 7bra [Septembra] 26º D[nia] Gubernij Litewsko Wilenskiey Pttu Trgo Kahału Karaimskiego w mieście Trokach będącego o nayduiących się męskiej y żenskiej płci Karaimach, Troki 515 op. 15, T. 204, k. $41-48$.

LPAHW, 1834, Revizskaâ Skazka tysâča vosimsot" tridcat" četvertago goda Aprelâ dvadcat' vosmogo dnâ dla Vilenskoj Gubernìi Uezdnago Goroda Trok" o sostoâščih" mužeska i ženska pola Karaimah, Troki 515 op. 15, T. 590, k. 282-300, 305-307, 318.

LPAHW, 1858, Revizskaâ skazka tysâča vosem'sot" pât'děsât" vos'mogo goda Aprělâ pervogo dla Vilenskoj Gubernìi uězdnogo Goroda Trok" o sostoâščih” mužeskogo i ženskogo pola dušah" obščestva meščan" Karaimov", Troki 515-25-112, k. 525-554.

PAARK, 1860, Metričeskaâ kniga o brakosočetaniâh, Perekop F. 241, op. 1, d. 1475.

RPW-HA, 1902a, Delo Semiona Kobeckogo, Glavnyj štab, Gaisin F. 400 Op. 9 d. 34273. RPW-HA, 1902b, Delo Semiona Kobeckogo, Glavnyj štab, Gaisin F. 400 Op. 17 d. 14088. RPW-HA, 1905, Delo Semiona Kobeckogo, Poslužnye spiski, attestacii i nagradnye listy oficerov russkoj armii, Kiev F. 409 Op. 1 d. 4118. 


\section{Opracowania}

Abkowicz, M., 2015, Towarzystwo edukacyjne „Limmud Tora”. Reforma szkolnictwa karaimskiego na początku $X X w$. $w$ Trokach $w$ świetle dokumentów, Almanach Karaimski 4: 147-165.

Abkowicz, M., Sulimowicz, A., 2010, Karaj jołlary - Karaimskie drogi. Karaimi w dawnej fotografii, Bitik, Wrocław.

Bałaban, M., 1927, Studja historyczne, skł. gł. Księgarnia M. J. Freid i S-ka; Drukarnia Korona, Warszawa.

1932-1934, Bł. P. Szymon Kobecki, Myśl Karaimska 10: 101-102.

Brodavko, R., 2005, Saksaganskij vozvraŝaetsa v Odessu, - F. Kohriht (red.), Derebasovskaja-Riŝelevskaâ: Odesskij Almanah, Izdatelskaâ organizaciâ „Plaske”, Odessa: 174-177.

Bruski, J.J., 2008, Hołodomor 1932-1933: Wielki Głód na Ukrainie w dokumentach polskiej dyplomacji i wywiadu, Polski Instytut Spraw Międzynarodowych, Warszawa.

Elâševič, B., 1993, Karaimy. Kn. 2. Karaimskij biografičeskij slovar (ot konca VIII v. do 1960 g.), Moskva.

Firkavičiūtè, K., 1997, Čypčychlej učma Trochka: Lietuva karajlarnyn jyrlary, Leidyklas Danielius, Vilnius.

Firkovič, M., 1989, Karaj jyrlary, Litovskij fond kultury, Vilnûs.

Fuki, A., 1995, Karaimy - synoviâ i dočeri Rosii, Interprint, Moskva.

Fuki, I., 2001, Skvoz veka i kontynenty, CFÉM, Moskva.

Hroch, M., 2008, Małe narody Europy: Perspektywa historyczna, Zakład Narodowy im. Ossolińskich - Wydawnictwo, Wrocław.

Kazas, M. (red.), 2006, Karaimskaâ Narodnaâ Encyklopedâ: Kultura krymskih karaimov (tûrkov), Izdatelskij dom „Gallina scripsit”, Sankt-Petersburg.

Kobeckaitè, H., 2006, Simon Kobeckis - Visuotine lietuviu enciklopedija, Mokslo ir enciklopedijų leidyklos, Vilnius 10: 326.

2012, Kniga učeta lic sostoâvših na osobom učete byvših belyh oficerov v organah GPU Ukrainy. T. 2. Otraslevoj Gosudarstvennyj arhiv Služby Bezopastnosti Ukrainy, Izdatel'stvo Saga, Har'kov.

Kobeckaite, H., 2011, Wieczory przy lampie Tatusia, Awazymyz 4 (33): 18-22.

Kobecki, S., 1932a, Burunhu kiuń midraszta, Karaj Awazy 3 (5): 30.

Kobecki, S., 1932b, Kim bołałyr, Karaj Awazy 2 (4): 17.

Kobecki, S., 1936, Jirłary Szymon Kobeckinin, Karaj Awazy 9: 16-21.

Kobecki, S., 1939a, Érbi Médad, Onarmach 3: 6.

Kobecki, S., 1939b, Tuzsuz, Onarmach 3: 7.

Kobeckij, S.A., 1904, Irlar": Stihotvorenía na razgovornom" narécii karaimov" zapadnyh" gubernii, Kiev.

Kobeckij, S.A., 1911a, Kolybel'naâ pěsnâ (Iry mamanyn" tëšagi katny âš" uvlunun"), Karaimskâ̂ Žizn’ 3-4: 19-20.

Kobeckij, S.A., 1911b, Kadril', Karaimskaâ Žizn' 5-6: 80-81. 
Kowalski, T., 1929, Karaimische Texte im Dialekt von Troki. Teksty karaimskie $w$ narzeczu trockiem (= Prace Komisji Orjentalistycznej Polskiej Akademji Umiejętności 11), nakładem Polskiej Akademii Umiejętności.

Krasnova, E., Drozdovskij, A., 2012, Odesskoe pehotnoe ûnkerskoe učiliŝe, - F. Kohriht (red.), Derebasovskaja - Riŝelevskaâ: Odesskij Almanah, Izdatelskaâ organizaciâ „Plaske”, Odessa: 106-121.

Kulczycki, S., 2008, Hołodomor: Wielki Głód na Ukrainie w latach 1932-1933 jako ludobójstwo: problem świadomości, Kolegium Europy Wschodniej im. Jana Nowaka-Jeziorańskiego, Wrocław.

Mardkowicz, A., 1936, Jirłary Szymon Kobeckinin, Karaj Awazy 9: 16.

1909, Obŝij spisok" oficerskim" činam" Russkoj Imperatorskoj Armii. Sostavlen" po 1-e ânvarâ 1909 g., Voennaâ Tipografâ, St. Peterburg.

1910, Obŝij spisok" oficerskim" činam" Russkoj Imperatorskoj Armii. Sostavlen" po 1-e ânvarâ 1910 g., Voennaâ Tipografâ, St. Peterburg.

1913a, Pamâtnaâ knižka Volynskoj gubernii na 1914 god", Volynskaâ Gubernskaâ tipografíâ, Žitomir.

1915, Pamâtnaâ knižka Volynskoj gubernii na 1915 god", Volynskaâ Gubernskaâ tipografíâ, Žitomir.

Rajca, C., Łesiów, M., 2005, Głód na Ukrainie, Wydawnictwo Werset; Polski Fundusz Wydawniczy w Kanadzie, Lublin, Toronto.

1932, Ribbiłer, kajsyłar hazzanłyk ettiłer Łuckada basłap burunhu yarymyndan XIX izjiłnyn, Karaj Awazy 3 (5): 16.

Saksaganskij, P., 1932, Teatri žittâ, Harkìv - Poltava

Sologub, K.N., 2010, Professionalnyj status volnoopredelâûsihsâ i ohotnikov Russkoj imperatorskoj armii i flota (1874-1917 gg.), Genealogiâ 13: 94-130.

1911, Spisok kapitanam" armejskoj péhoty po staršinstvu: Sostavlen" po 1-e Noâbrâ 1910 g., Voennaâ Tipografâ, S. Peterburg.

1905, Spisok" knig vyšedših" v" Rossì v" 1905 godu, Tipografiâ Ministerstva Vnutrennyh" Děl", S.-Peterburg 1905.

1912. Spisok" podpolkovnikam" po staršinstvu. Čast' I, II, III. Sostavlen" po 1-e Maâ 1912 g., Voennaâ Tipografâ, St. Peterburg.

1913b. Spisok" podpolkovnikam" po staršinstvu. Čast' I, II, III. Sostavlen" po 15-e Maâ 1913 g., Voennaâ Tipografâ, St. Peterburg.

Tinčenko Â., 2011, Kniga istreblennogo genofonda Ukrainy. Kniga učeta lic sostoâvših na osobom učete byvših belyh oficerov v organah GPU Ukrainy. T. 1. Otraslevoj Gosudarstvennyj arhiv Služby Bezopastnosti Ukrainy, Izdatel'stvo Saga, Har'kov: 3-20.

Tinčenko Â., 2012, „Tihij terror” protiv byvših oficerov v pervoj polovine 1030- $h$ godov. Kniga učeta lic sostoâvših na osobom učete byvših belyh oficerov v organah GPU Ukrainy. T. 2. Otraslevoj Gosudarstvennyj arhiv Služby Bezopastnosti Ukrainy, Izdatel'stvo Saga - Har'kov: 3-16. 
Towarzystwo Miłośników Historii i Literatury Karaimskiej, 1933, Pamięci Szymona Kobeckiego narodowego poety karaimskiego, Wilno.

1860, Volumina Legum: Prawa, konstytucye y przywileie Królestwa Polskiego, Wielkiego Xiestwa Litewskiego y wszystkich prowincyi nalezacych na walnych seymiech koronnych od Seymu Wiślickiego roku pańskiego 1347 aż do ostatniego Seymu uchwalone, przedruk zbioru praw staraniem XX. Pijarów w Warszawie, od roku 1732 do 1782 wydanego, Jozafat Ohryzka, Petersburg, https://pl.wikisource.org/wiki/Strona: Volumina_legum_T._7. djvu/113 [dostęp 15 października 2016].

1911b, Vybory trokskago gahama, Karaimskaâ Žizn' 3-4 (avgust" - sentabr"): 115-117.

Zajączkowski, A., 1926, Literatura karaimska. Szkic bibliograficzny, Myśl Karaimska 1 (3): 7-17.

Zajączkowski, A., 1928, „Pieśni” Kobeckiego, Myśl Karaimska 1/4-5: 13-24.

Zajončkovskis, M., 1997, Karaimai kariuomeneje: Karajlar javanlychta. Karaims on military service. Karaimi na żołnierce. Karaimy v armii, Lietuvos nacionalinis muziejus, Vilnius.

Zajončkovskis, M., 2005, Karaimai kariai. Voiny karaimy. Karaimi wojskowi, Spausdino UAB „Pozicija”, Vilnius.

\section{Źródła internetowe}

Dubenskij, D. (red.), 1904-1905, Letopis vojny s Âponiej. Ežeedelnyj illûstrovannyj žurnal: Georgievskie kavalery za vojnu s Âponiej 1904-1905 gg., Sankt-Petersburg, http://genrogge.ru/hwj/hwj-gkav.htm [dostęp 15 października 2016].

Hrywna, I., 2010, Dlaczego Ukraincy kochaja Szewczenkę, http: //ukraincy.wm.pl/930,Dlaczego-Ukraincy-kochaja-Szewczenke.html [dostęp 15 października 2016].

Mihailov, S.S., 1999, Iz istorii karaimskoj diaspory v Moskve v XIX-XX vv., Vostok 4: 77-83, http://www.karaims.com/pdf_s/Mihaylov.pdf [dostęp 15 października 2016].

Volkov, S., 2014, Baza dannyh no 2 „Učastniki Belogo dviženiâ v Rossii” po sostoâniû na ânvar' 2014 goda, www.swolkov.org [dostęp 15 października 2016]. 


\section{Aneks I}

F. 400 Op. 9 d. 34273

\section{ДЕЛОПРОИЗВЛЬ УПРАВЛЕНИЯ ГАЙСИНСКОГО УЕЗДНОГО ВОИНСКОГО НАЧАЛЬНИКА СЕМЕН АЗАРЬЕВИЧ КОБЕЦКИЙ (RPW-НА 1905). \\ г. Гайсин Киевской губернии.}

18 апреля 1902 г. Кобецкий был подан на имя Императора установленный законом реверс на увольнение (досрочное ) со службы из - за расстроенных домашних обстоятельств. Жительство по отставке: г. Симферополь.

\section{ПОСЛУЖНОЙ СПИСОК}

Родился 29 июля 1857 г. из мещан г. Троки Виленской губернии. Вероисповедания Караимского, окончил курс Одесского пехотного юнкерского училища по 2 разряду.

В службу вступил согласно приказа от 25. 01. 1878 г. в переменный состав 50 пехотного запасного батальона на правах вольно определяющего по 3 разряду.

- 19. 09. 1878 г. - зачислен в Одесское юнкерское училище.

- 09. 06. 1879 г. - переведен из младшего класса в старший.

- 10. 09. 1879 г. - произведен в унтер-офицеры.

- 19. 07. 1880 г. - по окончаний курса переименован в портупей юнкера.

- 23. 07. 1880 г. - прибыл из училища в часть.

- 30.09. 1880 г. - переименован в подпрапорщики.

- 15. 03. 1881 г. - произведен Высочайшим приказом в прапорщики с переводом в 52-ой Виленский пехотный его Императора Высочества Великого Князя Кирилла Владимировича полк.

- 08. 04. 1881 г. - Прибыл в полк.

- 26.03. 1883 г. - 14. 09. 1884 г. - исполнял должность квартирмейстера и зав. околодком полка в Крыму, в Керчи.

- 19. 05. 1883 г. - 14. 09. 1883 г. - лагерным полицмейстером

- 14.09. 1884 г. - произведен в подпоручики.

- 25. 08. 1884 г. - 03. 04. 1885 г. - зав. полковой швальней.

- 25. 01. 1886 г. - Утвержден в должность полкового казначея. 
- 25. 06. 1887 г. - сдал должность полкового казначея.

- 22 июля 1887 г. - переведен Высочайшим приказом в Управление Мало архангельского Уездного Воинского Нач.-ка делопроизводителем с зачислением по армейской пехоте.

- 04. августа 1887 г. - Прибыл и зачислен в списки.

- 05. ноября 1888 г. - Высочайшим приказом произведен в поручики.

- 28. августа 1892 г. - Высочайшим приказом произведен в штабс-капитаны.

- 25. декабря 1893 г. - Награжден орденом Св. Станислава 3 ст.

- $\quad$ 07. августа 1896 г. - Высочайшим приказом уволен от службы для определения к статским делам с переименованием в коллежские асессоры.

- 19. августа 1896 г. - Исключен из списков Управления с прекращением содержания.

- 05. ноября 1897 г. - Высочайшим приказом определен в службу Управления Гайсинского Уездного Воинского Начальника исправляющим должность делопроизводителя с зачислением по армейской пехоте с прежним чином - штабс-капитана.

- 23. марта 1899 г. - Утвержден в должность делопроизводителя.

- 06. августа 1900 г. - Высочайшим приказом за выслугу лет произведен в - капитаны.

- В гражданской службе и по выборам дворянства не служил.

Всемилостивейших рескриптов и Высочайших благоволении - не получал. 20. мая 1902 г. Высочайшим приказом уволен по домашним обстоятельствам от службы подполковником и с мундиром .

Капитан

Холост, недвижимого имущества не имеет , наказаниям или взысканиям по служебным приговорам - не подвергался.

Временно исправлял должности Мало Архангельского Уездного Воинского Начальника (2 раз) и потом Гайсинского Уездного Воинского Начальника (2 раза). В службе обер-офицера сего не было обстоятельств лишающих его права на знак отличия беспорочной службы (2 раза).

- 23. 03. 1912 г. - Определен на службу Сквирского Уездн. Военного Начальника на должность - Завхоза Дубненского дисциплинарного батальона. 


\section{Aneks 2}

F. 40o. op. 1. d. $140882 \mathrm{r}-3 \mathrm{r}$

Всёпросветительный Державнейшый Великий Государь Император Николай Александрович Самодержавец Всероссийский Государь Всемилостивый

[2 znaczki skarbowe wartości 60 kopiejek]

Просит Делопроизводитель Управления Гайсинского Уездного Воинского Начальника капитан Семён Азаревич Кобецкий о нижеследующим:

Расстроенные домашние обстоятельства мешают меня возможности продолжать службу Вашего Императорского Величества и потому прошу представляя при этом установленный законом реверс, всеподданнейше прошу: к сему

Дабы повелено было уволить меня от службы с награждением следующим чином и мундиром. Г. Гайсин Апреля 18 дня 1902 года. К подаянию надлежит по команде. Сие прошение со слов просителя писал писать Ахтон Гненный

Капитан Семён Азаревич Кобецкий руку приложил.

[Verso]

Я, нижеподписавшийся, даю сей реверс в том, что если последует разрешение об увольнении меня от службы, то о казённом содержание просить нигде не буду.

Жительство по отставке буду иметь в г. Симферополе Таврической Губернии.

Апреля 18 дня 1902 года г. Гайсин

Делопроизводитель Управления Гайсинского Уездного Воинского Начальника капитан Семён Азаревич Кобецкий 


\section{Ryciny}
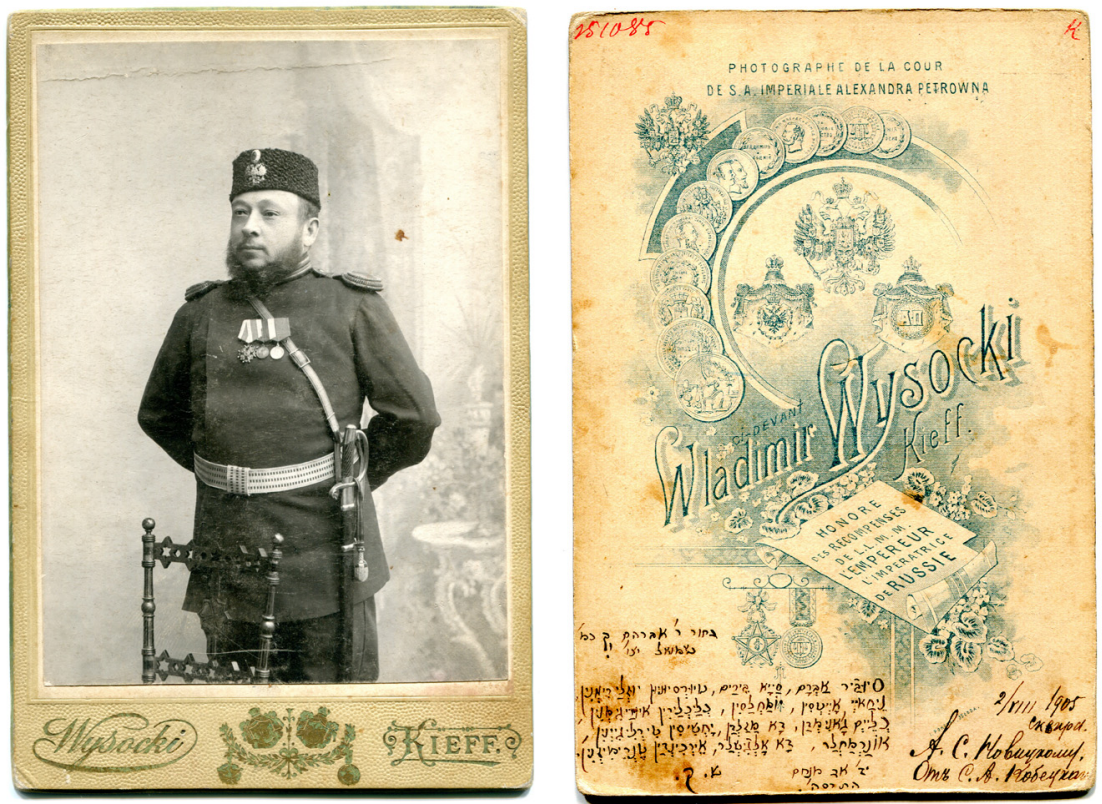

Ryc. Ia-b. Fotografia portretowa Szymona Kobeckiego, zadedykowana A.S. Nowickiemu, datowana Skwyra, 2 VIII 1905. Dedykacja w j. hebrajskim: Kawaler ribbi Abraham, syn wielmożnego pana Szemoela, niech jego Skała błogosławi go i zachowa. Wierszyk w j. karaimskim:

Suwáar Awram, saja b’éám, t'urśuńuń juźlarimniń.

$N^{\prime}$ echaj ajtsyn, jomachłasyn klaklariń üragimńn.

Klejm džanymdan da mazałdan jaxšysyn tirligijniń,

Onarmaxłar da ałxyšłar erkińd'ań Tenrimiźniń.

S. $K$.

14 av menaxem 5665

Drogi Abramie, daję Ci oto wizerunek mego oblicza,

Niechaj przemówi, niech opowiada o życzeniach mego serca.

Chcę z całej duszy, by los obdarzył Cię dobrym życiem,

Sukcesami i błogosławieństwami z woli naszego Boga.

Sz. K.

14 [dzień miesiąca] aw menachem 5665 


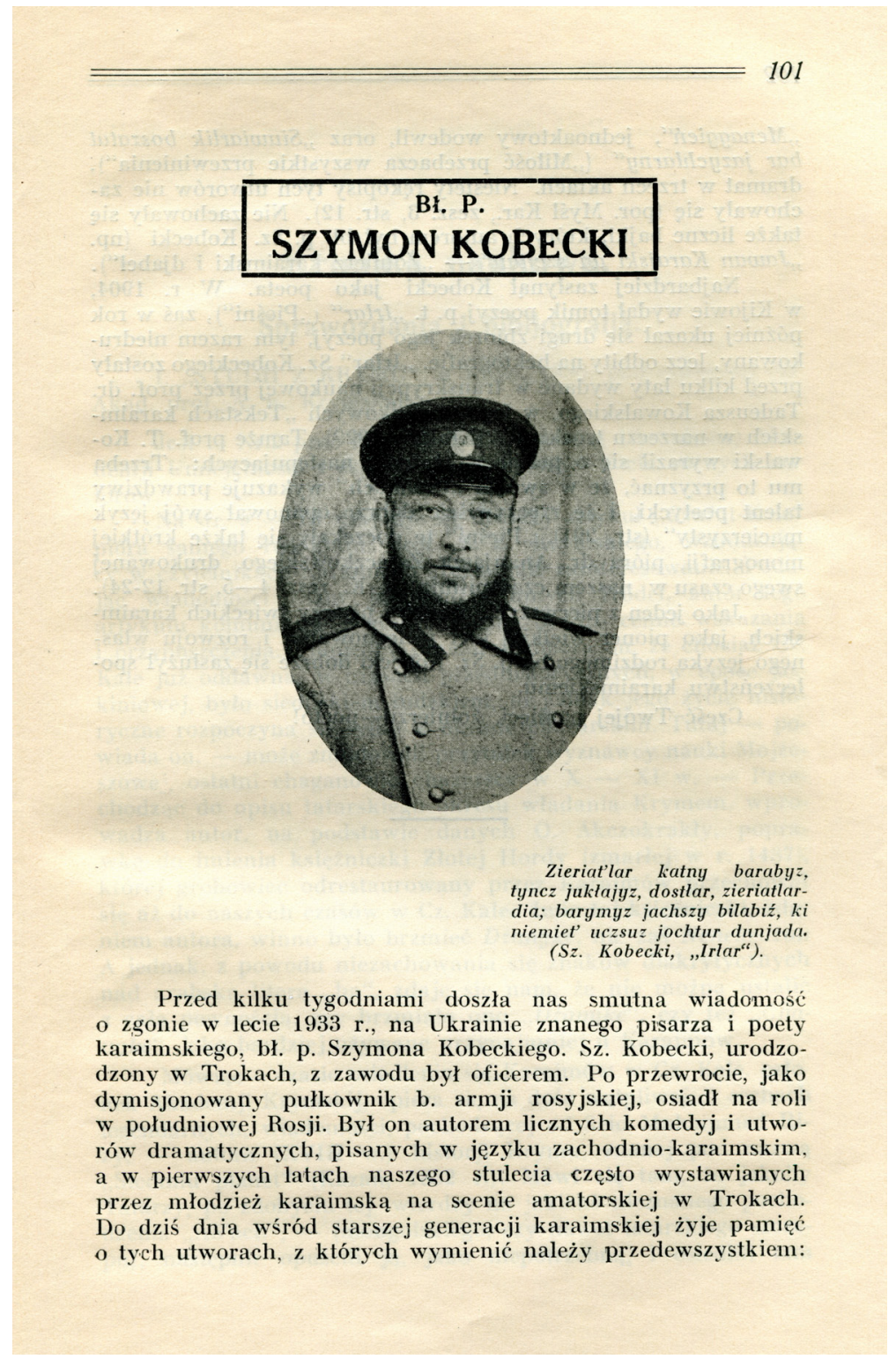

Ryc. 2a. Wykadrowany portret Kobeckiego zamieszczony przy nekrologu w „Myśli Karaimskiej” (z. 10, 1932-1934, s. 101). 


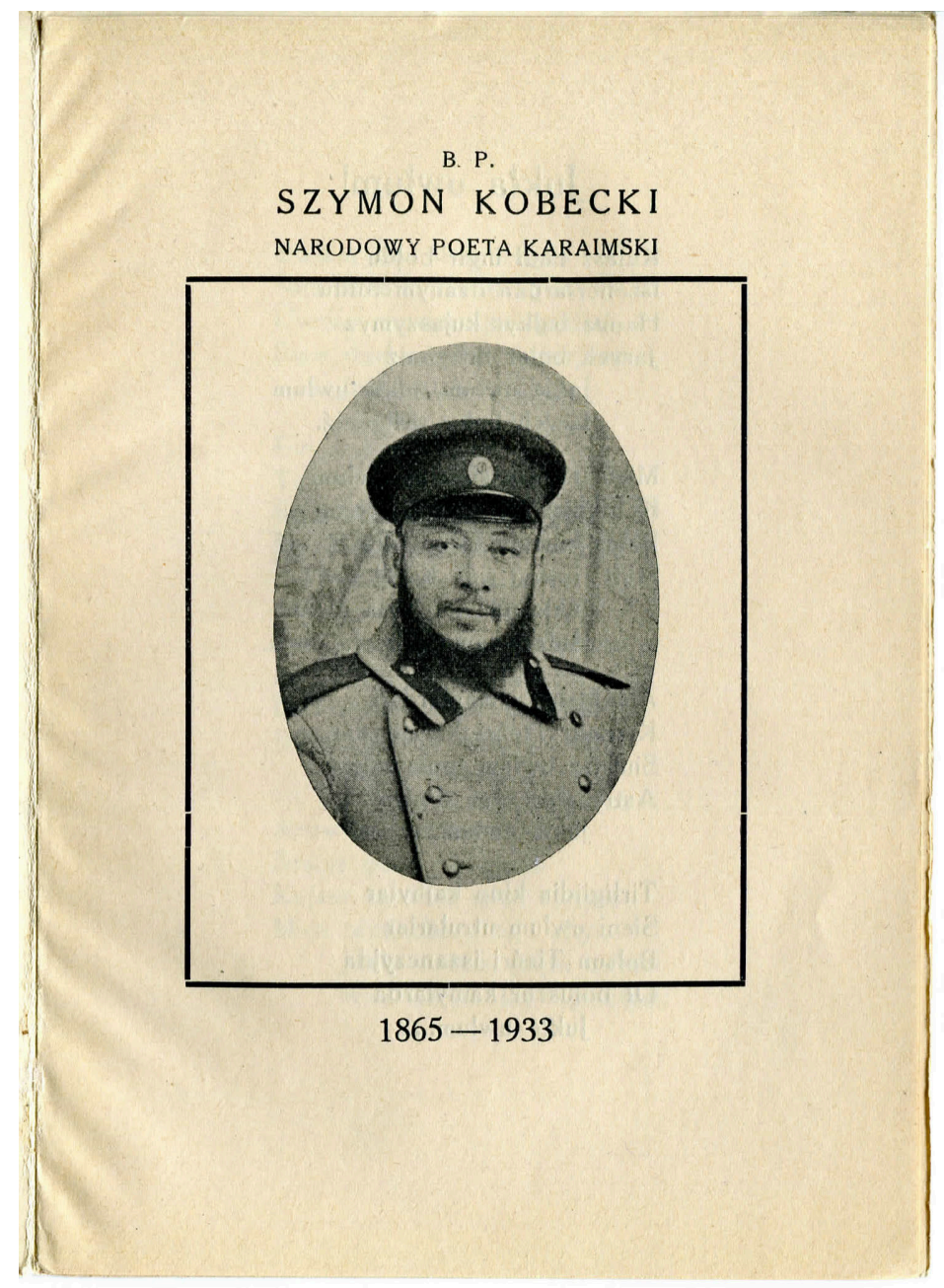

Ryc. 2b. Strona tytułowa pamiątkowej broszurki wydanej przez Towarzystwo Miłośników Historii i Literatury Karaimskiej w Wilnie w roku 1933. 


\title{
JIRŁARY SZYMON KOBECKINYN
}

\begin{abstract}
Ystyradohac sifteri isne „Karaj Awazynyn" tiziwłerin i $\mathbf{k}$ karaj jircyłarnyn, ornatabiz bu fornu nece sajłahan jirłaryn $\mathrm{ucmakly}$ Szymon Kobeckinyn.

Sahyndyrybiz nece sezde tirligin jircynyn da bitisin anyn ałheminin. Szymon Kobecki tu w d u Trokta ekińci jarymynda askan jizjiłnyn. Jigit jiłłaryndan ezlendi ceriw zachme-

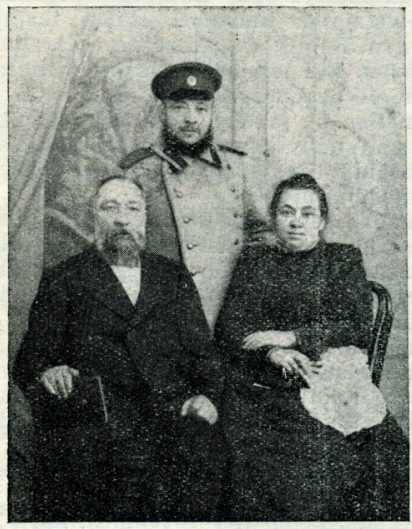

Jirey (turad) birden ez ezinkiłeribe

tine da jetti jergesin pułkowniknin e e r i w chałkynda Rosijanyn. Tismeginden sortun caratnyn ołturdu sakada walajatynda $\mathrm{K} \mathrm{i-}$ jownun, kajda ałyndy isine saban sirmeknin. $\mathrm{Bu}$ awur zachmette da katy tirlikte asty kałdyhy anyn kinłerinin. Ystyryłdy 1983 jiłda.

Ajamahan edi anar ałhemi jircynyn. Jirłary anyn burunhu for eyktłar jarykka Kijowda 1904 jiłda da bastyrhan ediłer rus-otijotłarba. Sondra ornatty ałarny prof. Tadeusz Kowalski ez biliwli isinde: „Teksty karaimiskie w narzeczu trockiem “ (cykty Krakowda 1929 jiłda). Jirłary ìcin Kobeckinyn jazdy artykuł Ananjasz Zajączkowski („Pieśni“ Kobeckiego), kajsy ornatkandy IV-V defterinde wachtłyknyn "Myśl Karaimska“. Baska jirłardan Kobecki jazdy nece tiziw scenaga, kajsyłarny jigit ełen Trokta kergiziredi askan jiłłarda. Bar anyn tiziwłeri jazhandłar sezibe Trokłu Karajłarnyn*).
\end{abstract}

\section{J A N H Y 1 Ł B A!..}

Keczásińdá janhy iłnyn,

Karanhyda kar aharat,

Türsünüńdá erkisziniń

Troch aszary małach barat.

Kelat esiná małachnyn, Ki bu karnyn achłyhyna Tenászkejt jołu adamnyn, Tursejt kertilik ałnyna.
Sahyszłary üzüldülar Astry küczlü awazłardan, Sezlej, küla, terk czychtyłar Karajkalar bir azbardan.

Kacza keldilar ałnyna, Tanymydłar bu kiszini, Kyczchyradłar utrsuna: - Terkrák biźgá ajt szemijni!.."

*) Fonetykasyn oł seźnin awurdu kajtarma bitin duhrułukba jumusłanadohac lech otijotłarba. Uchuwcułarymyz kłerłer alma esine, ki bunda otijot a symarłahan (á) turhuzhandy ol orunłarda, kajsyłarda kerekti lechca turhuzma "ia", jemese urusca ${ }^{\prime}{ }^{*}$. Jimsak ${ }^{\mu}{ }^{\mu}$-den son $a$ uchuład ałaj chaz á; $\ddot{u}$ uchuład ałaj chaz lechea , „іи", urusca „ю“. Ernek była: 1, keczásindá=kecziasińdia=кечясиньдя; 2) türsünüńdá=tiursiuniuńdia=тюрсюнюньдя; 3 , keldilar=keldilár=кельднляр.

Ryc. 3. W całości fotografia z „Myśli Karaimskiej” została opublikowana w „Karaj Awazy” (nr 9, 1936, s. 16). Podpis głosi: „Poeta (stoi) razem ze swoimi bliskimi”. 

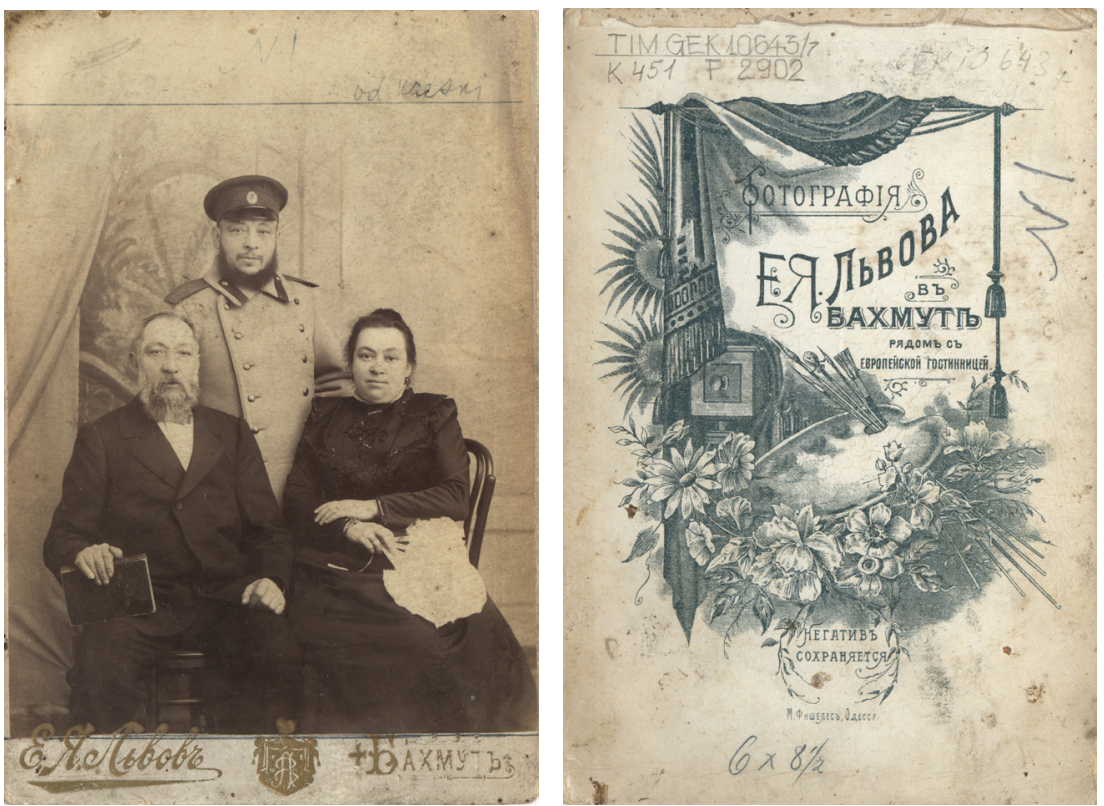

Ryc. 4a-b. Oryginał fotografii wykorzystanej w publikacjach.

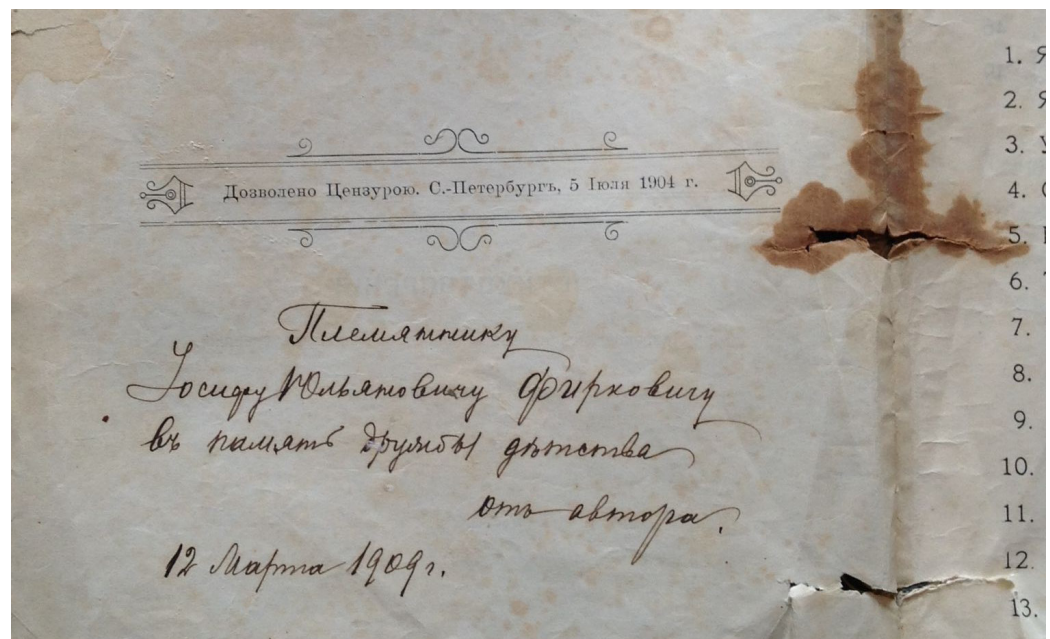

Ryc. 5. Dedykacja autora dla Józefa syna Juliana Firkowicza na egzemplarzu Irlar, 1909 r. 

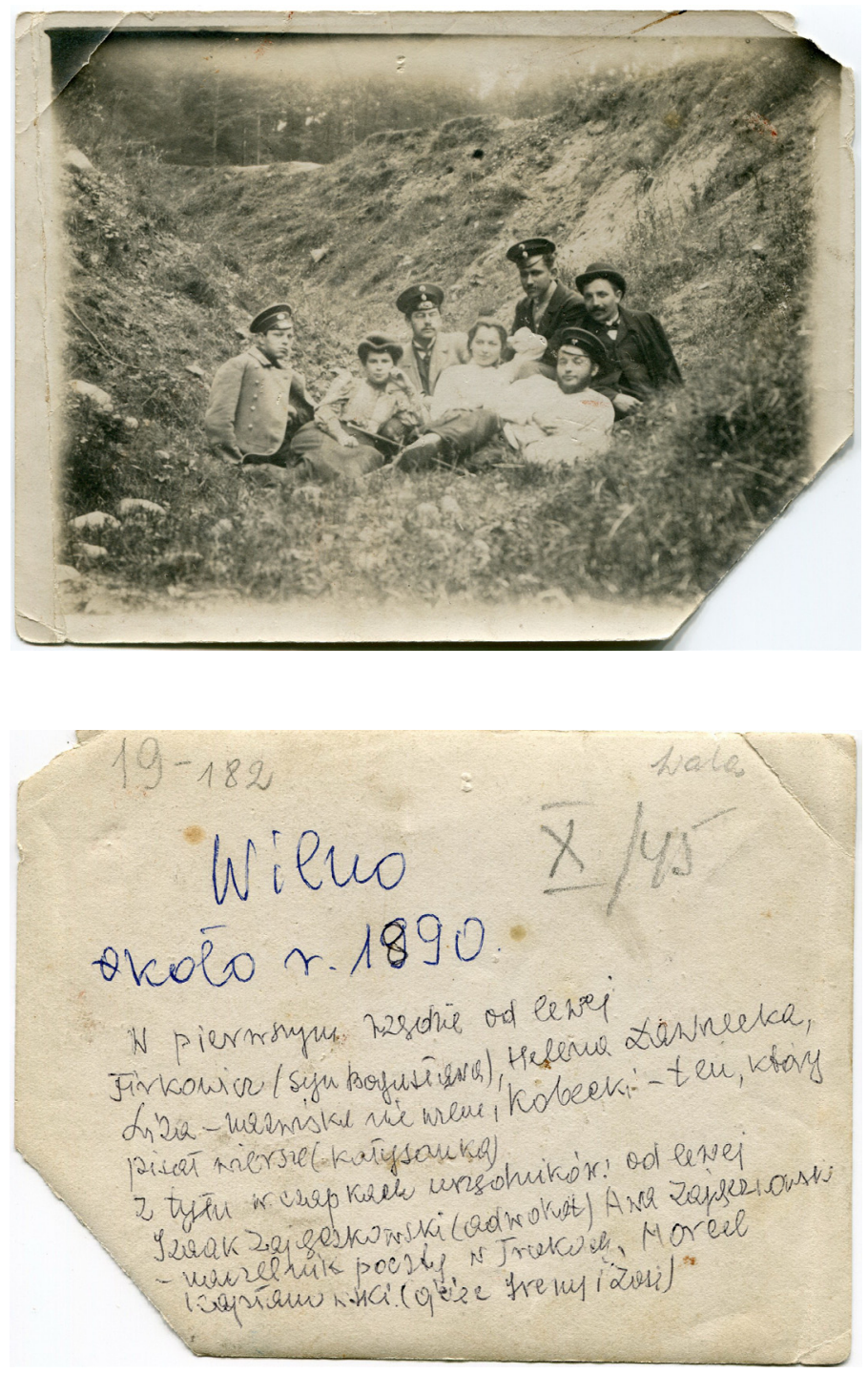

Ryc. 6a-b. Zdjęcie z albumu Heleny „Loli” z Ławrzeckich Łobanosowej (1882-1958). W dolnym rzędzie pierwszy z prawej mężczyzna mylnie zidentyfikowany przez córkę Loli, Walentynę, jako „Kobecki - ten, który pisał wiersze (kołysanka)”. Zdjęcie zostało wykonane prawdopodobnie w końcu lat 90. XIX w.. 
